\title{
Covid-19 and global clothing retailers' responsibility to vulnerable workers: NGO counter-rhetoric
}

\author{
Nglaa Ahmad \\ PhD candidate (Accounting) \\ University of Aberdeen \\ n.ahmad.18@abdn.ac.uk \\ Shamima Haque ${ }^{1}$ \\ Senior Lecturer in Accounting \\ University of Aberdeen \\ Email: shamima.haque@abdn.ac.uk \\ Muhammad Azizul Islam \\ University of Aberdeen \\ Email: azizul.islam@abdn.ac.uk
}

Chair in Accountancy and Professor in Sustainability Accounting and Transparency

Reference:

Ahmad, N., Haque, S., and Islam, M. A. (forthcoming), Covid-19 and global clothing retailers' responsibility to vulnerable workers: NGO counter-rhetoric, Accounting, Auditing \& Accountability Journal

\footnotetext{
${ }^{1}$ Corresponding author
} 


\title{
Covid-19 and global clothing retailers' responsibility to vulnerable workers: NGO counter-rhetoric
}

\begin{abstract}
Purpose: This article examines how NGOs' narratives portray the vulnerability of workers in global clothing supply chains during the Covid-19 crisis.

Design/methodology/approach: The research analyses the rhetoric in global clothing retailers' and NGOs' counter-rhetoric during the first seven months of 2020.

Findings: During this period, retailers employed rhetorical strategies to legitimise irresponsible actions (corporate hegemony prevailed), while NGOs embraced forms of counter-rhetoric trying to delegitimise the retailers' logic, stressing the role of neoliberalism in worsening the situation.

Originality/value: We contribute to the literature by providing new insight into the consequences of Covid-19 for retailers' neoliberal practices and the livelihood of workers in global supply chains. Our findings extend our knowledge about retailers' Covid-19 measures: these have contributed to the plights of workers working for their supply factories in the global South.
\end{abstract}

Keywords: Covid-19, neoliberalism, NGO counter-rhetoric, global clothing retailers, transparency, workers' vulnerability 


\section{Introduction}

Previous research (e.g. Islam, Deegan and Haque, 2020; Islam, Deegan and Gray, 2018) has found that, although global clothing retailers have put in place social responsibility disclosures, moral narratives and social audit, conditions of workers employed in garment factories have not improved over time. We extend this research by looking at how retailers' practices (including corporate social responsibility (CSR) disclosures and accountability practices) have affected workers' plights during the Covid-19 pandemic. In particular, during this period, a narrative of exploitations and slavery has grown among non-governmental organisations (NGOs), criticising neoliberal policies and their beneficiaries (such as retailers based in the global North and their suppliers in the global South). The research is imperative, given that NGO rhetoric and persuasive arguments have played a crucial role during the Covid-19 crisis in spurring demand and pressures upon retailers to be accountable and responsible for the livelihood of workers within their supply factories in underprivileged Southern nations. Growing research is documenting counter-accounts, counter-narratives and counter-rhetoric by NGOs and social movement organisations (see the recent work by Semeen and Islam, 2020). However, little is known about how NGOs and other partners (e.g. media) use counter-accounts or rhetorical/persuasive arguments against corporations' irresponsible practices during a particular crisis or pandemic. Given this research gap, we aim to offer critical insights into how NGOs' rhetoric and arguments challenged the conduct and responsibility of global retail companies within their global supply chains during the Covid-19 pandemic.

Based on analysis of the rhetoric in publicly available documents issued by global retailers and NGOs during seven months of the pandemic period - January to July 2020 - this research shows that NGOs are crucial global actors in exposing retailers' lack of transparency, and failure of responsibility to protect workers who are vulnerable. While global retailers use different rhetorical tactics - including manipulation, flawed justification, avoidance, silence and others - to get away with breaching basic workers' rights during the crisis, counter-rhetoric by NGOs exposes retailers' contributions to hegemony, inequality and the greater vulnerability of workers during that period. In other words, our rhetoric analysis focuses on how neoliberal retailers' practices in relation to workers' rights within global supply chains are contested and challenged by NGOs' criticisms of those retailers' irresponsible/self-interested behaviour during the crisis. ${ }^{2}$

This paper contributes to two streams of critical accounting literature-neoliberalism (see for example Islam et al., 2020; Chiapello, 2017; Morales et al., 2014; Cooper et al., 2010) at the macro and micro levels (Arnold, 2009; Ellwood and Newberry, 2007; Ala and Lapsley, 2019) and counter-accounts or rhetoric (Brennan \& Merkl-Davies, 2014; Semeen \& Islam, 2020; Lehman et al., 2016) - by providing new insights into how, during a global pandemic, retailers' neoliberal practices impact on the livelihood of workers in global supply chains. NGO narratives and persuasive arguments during the Covid-19 pandemic reveal fundamental flaws

\footnotetext{
${ }^{2}$ We acknowledge that different stakeholder groups (such as regulators, and international bodies like UN, WHO) might pay greater attention to how the pandemic continues to impact negatively on lives and livelihoods around the globe, showing concern for the public health crisis and economic devastation attributable to the pandemic (UNCTAD, 2020). However, the focus of this research is on how NGOs and other partners (e.g. media) use rhetoric and persuasive arguments associated with a particular crisis.
} 
in neoliberalism at the macro level, allowing global retailers (the micro level), over the last three decades, to diffuse the social responsibility practices they have adopted-disclosures, social audits, codes of conduct and so on. We argue that, during the pandemic, neoliberalism has taken a new turn by disregarding all kinds of social responsibility practices; that retailers have been irresponsible and exploited the vulnerability of workers in global supply chains. Our findings are crucial because without NGOs' narratives and rhetoric on retailers' responsibility and transparency, we would not be able to extend our knowledge about how retailers have reacted to Covid-19 and contributed to the plight of workers working for their supply factories in the South.

The paper is structured as follows. Section 2 considers the theoretical lens and relevant literature, highlighting a key research gap. Section 3 presents our research method. This is followed, in Section 4, with results and analysis of this study. The final section presents our conclusions and summarises the major arguments of this paper.

\section{Neoliberalism during Covid-19 and counter-accounting literature: key research gap}

Over the past four decades, neoliberalism has touched almost every sphere of the private and public lives of people across the globe, through privatisations, free trade policies and moving production to Southern nations. While corporations and many economic policymakers claim neoliberalism has increased economic progress, it has been criticised heavily for contributing to increasing global inequality, ${ }^{3}$ and for empowering corporations to compete with countries for economic power (Connolly \& Kaisershot, 2015). ${ }^{4}$ Historically, neoliberalism, as one of several experiments in economic development during the modern era, has been "a "bad idea" for the subject, but not for [its] designers and local elites associated with them. This pattern continues until the present: pleasing profit over people' (Chomsky, 1999, p.26). It is evident that socio-economic injustice has been on the rise worldwide due to neoliberal policies being exercised by MNCs and promoted on a global scale via bodies such as the International Monetary Fund (IMF), the World Bank (WB) and the World Trade Organization (WTO) (Chomsky, 1999; Navarro, 2020). In line with such critical discourse of neoliberalism, critical accounting research (Arnold, 2009; Ellwood, and Newberry, 2007; Ala and Lapsley, 2019) promises to offer new insights into the links between the macro world of neoliberalism (crisis/pandemic, tension in global capitalism, global hegemony) and the micro world where organizations operate, discourse occurs, and ultimately accountability is assigned.

During crises (whether financial crisis or global pandemic), neoliberalism 'benefits [the] wealthy at the expense of [the] general public' (Chomsky, 2016). In particular, the Covid-19 pandemic 'is a vivid illustration of the great damage that the neoliberal era has done to the large majority of the population' (Chomsky, 2020). Within the broader (perhaps interdisciplinary) field and public sphere, many see the impact of Covid-19 and the behaviour of dominating actors (such as MNCs) as a 'colossal failure' of neoliberalism (see for example, Magdaleno, 2020; Navarro, 2020; Neilson, 2020; Bryant et al., 2020; Kılıç, 2020). During the pandemic,

\footnotetext{
${ }^{3}$ Oxfam found that the world's 26 richest people own as much as the poorest $50 \%$ (The Guardian, January 21 2019).

${ }^{4}$ Each of the 25 biggest companies have larger revenues than some countries' GDP.
} 
along with critical academics, civil society groups including NGOs have used counter-rhetoric to challenge the neoliberal hegemony in global trade.

Without necessarily using the term 'neoliberalism', prior counter-accounting research has highlighted that counter-accounts or rhetoric may confront it by mobilising rhetoric that communicates the negative consequences of abuse, particularly when the problem is perpetuated through imbalanced power relations or systems of governance (Tregidga, 2017; Vinnari \& Laine, 2017). Prior research, in particular, has analysed counter-rhetoric mobilised by NGOs and social movements to make heard the voices of some vulnerable groups by exposing abuses or inequalities perpetuated by elites and simultaneously created new visibilities, and new calls for action to stimulate change (Denedo et al., 2017; Gallhofer et al., 2006; Tregidga, 2017; Vinnari \& Laine, 2017). A few studies have specifically focussed on neoliberalism (see, for example, Lehman et al., 2016), showing how a counter-account challenges hegemonic ideology by making opposing accounts visible that could delegitimise dominant neoliberal representations. Other research in the critical accounting domain, without necessarily focussing on counter-accounts/rhetoric, showed how, in crises, accounting practices are constructed to maintain the neoliberal agenda (Merino et al., 2010; Morales et al., 2014). Accordingly, our research aims to highlight neoliberalism as global hegemony by focussing on both corporate rhetoric and counter-rhetoric used by NGOs to challenge corporate hegemony within global supply chains. In other words, through NGOs' counter-narratives, we attempt to connect neoliberalism's global hegemony (macro) with firm-level (micro) behaviour driven by self-interest.

While the neoliberal doctrine is devoted solely to self-enrichment or self-interest-driven behaviour, within the public sphere, NGOs and social activists have launched crucial challenges to the doctrine. NGOs' activisms and counter-accounts are often seen in the public domain as holding macro-level actors such as states and international governmental organisations, and micro-level actors such as corporations, publicly accountable. Previous research has found that corporate social accountability practices within the supply chains in developing countries are influenced by NGOs' activities (Deegan \& Islam, 2014). NGOs and media often play emancipatory roles to shape the public perception of corporations' accountability practices, which in turn influences organisations to change their practices (Deegan \& Islam, 2014). We can see that crises like Covid-19 surface long-standing tensions between corporations and NGOs, making the tension visible and manifest in ways in which they usually are not.

This study attempts to show the problems raised by the role of global retail MNCs (global retailers) during Covid-19. MNCs have concentrated economic power and can now compete on equal terms with many Northern countries (Connolly \& Kaisershot, 2015). Historically, the way neoliberalism has encouraged MNCs to gain power has had profound effects on the free exercise of their responsibility to the community where they engage or operate (Shamir, 2008; Sikka, 2011). Growing research has documented that MNCs' adoption of neoliberal corporate practices - including CSR disclosures, codes of conduct, factory audits - has sought legitimacy rather than created accountability to the broader community (Islam et al., 2018, 2020). Given that, the Covid-19 pandemic provides a unique context for how neoliberalism (at a macro level) and corporate practices (at the micro level) contribute to the plight and vulnerability of workers within supply chains (Islam, 2020) — and to understand a wave of resistance and narrative opposing corporate practices, the context deserves immediate research attention. 


\section{Research Method: Rhetoric analysis}

Rhetoric analysis deals with rhetoric or persuasive texts and explains what is happening in them. It identifies the way a text communicates, examining the strategies it employs and how it persuades us of its point of view. Previous accounting research showed that organisations use rhetorical strategies along with particular disclosures (for example, Semeen and Islam, 2020 ) to perpetuate domination (Semeen \& Islam, 2020; Suddaby \& Greenwood, 2005). On the other hand, NGOs and civil society organisations use 'counter-rhetoric' to expose or challenge injustice created by organisations (Semeen and Islam, 2020). By drawing on literature focusing on forms of counter-rhetoric or persuasive argument that delegitimise dominant corporate logics and values (Erkama \& Vaara, 2010; Fincham \& Forbes, 2019), we analyse how the continuing Covid-19 crisis has exposed irresponsible actions by global retailers within their supply chains. In this paper, we examine the use of rhetorical strategies by retailers to legitimise their claims and actions, and counter-rhetoric by NGOs to delegitimise retailers' claims and persuade the wider community to protect workers' rights in global supply chains during the pandemic. We argue that the use of rhetoric is likely to be more pronounced during crises or public controversies, to mobilise public support.

During the pandemic, generally, press releases have been utilised by retailers to declare a position on a specific matter, whilst NGOs have tracked retailers' actions and used their narratives (in press releases and news media) to start the public discussion(s) to highlight the particular issue(s). For rhetoric analysis, we relied on publicly available reports-108 documents (Table 1) from 1 January to 31 July 2020-largely focusing on the responsibility of global retailers (mostly based in the UK, the USA, Australia, Canada and EU countries) in relation to workers' rights within their supply chains in Southern countries such as Bangladesh, China, India, Myanmar, Indonesia (and others). We used online platform and search tools and searched extensively to collect all relevant documents. The data is used to provide illustrations (exemplary statements, narratives, rhetoric) for developing a general understanding of legitimating and delegitimating rhetorical strategies and dynamics during the pandemic.

Table 1. Data Types and Sources

\begin{tabular}{|l|l|l|l|}
\hline \multicolumn{1}{|c|}{ Data types } & $\begin{array}{l}\text { Number of } \\
\text { documents }\end{array}$ & \multicolumn{1}{|c|}{ Sources } & \multicolumn{1}{c|}{ Major organisations' documents } \\
\hline $\begin{array}{l}\text { Corporate } \\
\text { statements (press } \\
\text { releases), } \\
\text { disclosures and } \\
\text { reports }\end{array}$ & 44 & $\begin{array}{l}\text { Companies' } \\
\text { websites } \\
\text { reports }\end{array}$ & $\begin{array}{l}\text { Asda, Best Seller, C\&A, Primark, Kohl's, } \\
\text { H\&M, New Look, John Lewis, Asos, M\&S, } \\
\text { Next, Pentland, Sainsbury's, Tesco }\end{array}$ \\
\hline $\begin{array}{l}\text { Novid-19 } \\
\text { guidance reports }\end{array}$ & 6 & NGOs' websites & $\begin{array}{l}\text { Oxfam, CCC, WRC, Remake, LBL, BHRRC, } \\
\text { Fibre2Fashion, IndustriALL, Global Union, } \\
\text { HRW, Fair Wear, IOE, ILO, ILRF, ITUC, } \\
\text { Fashion United, OEE, Global Social Justice }\end{array}$ \\
\hline
\end{tabular}


Drawing upon previous research on organisational rhetorical strategies (for example, (Benoit, 1995; Semeen \& Islam, 2020; Shrives \& Brennan, 2017), we followed three steps to analyse texts' rhetoric:

Preliminary comprehension of the data We read publicly available documents produced by retailers, NGOs and political leaders. This assisted us to grasp and code rhetoric and counterrhetoric used by different social actors regarding working conditions in the global clothing supply chains.

Coding After comprehension, initial codes were generated. We embraced a holistic coding system to get insights into prominent themes: mapping out, for all available documents, who did and said what, where and when. This mapping was revised several times during the analysis to sharpen accuracy. The initial coding generated a number of themes under two major categories: irresponsible actions and related rhetoric by retailers, and counter-rhetoric by NGOs.

Data analysis framework First, following counter-accounting literature (Semeen \& Islam, 2020; Tregidga, 2017; Vinnari \& Laine, 2017), we identified NGO accounts illustrating retailers' irresponsibility and lack of transparency associated with workers' vulnerability. Drawing on past research and by reading documents, we considered a number of themes describing organisational rhetorical strategies, including rhetoric of justification, rhetoric of misleading commitment, rhetoric to divert attention and rhetoric of silence - these types of persuasive argument were used by retailers and NGOs to legitimise or delegitimise each others' actions on workers' vulnerability. The data was then analysed via illustrations of narrative and rhetoric strategies used by retailers and counter-rhetoric used by NGOs in relation to workers' vulnerability in global supply chains during the pandemic.

\section{Illustrative accounts by NGOs of retailers' adding to the vulnerability of workers}

A report by the International Labour Organization (ILO) documented that by mid-April 2020, in many Southern nations (mostly in Asia) garment manufacturers had been forced to stop production or reduce capacity by the major disruption of end-to-end global supply chains owing to the emerging health crisis (ILO, 2020). The ILO report also recorded that, with consumers staying at home and many physical stores being closed, Europe- and US-based buyers began cancelling and suspending orders from suppliers. Islam's (2020) Conversation piece highlighted similar situations in Bangladeshi factories, presenting a dire picture of working conditions up to June 2020:

Western multinational companies have started cancelling orders, some reportedly without paying for production costs already laid out. Millions of workers are facing destitution having been sent home without pay. As of April, more than US\$3 billion in orders to around 1,150 factories were in limbo, leaving around 2.8 million workers, mostly women, facing poverty and hunger.

In this article, we investigate how NGOs have launched name-and-shame campaigns via counter-rhetoric or persuasive arguments against some high-profile clothing retailers that have failed to honour contractual obligations with suppliers through cancelling, postponing or renegotiating prices for their orders. A group of NGOs, including Labour Behind the Label (LBL), Traidcraft Exchange, Remake and the Worker Rights Consortium (WRC), have set up a Covid-19 tracker to track high-profile brands that are honouring obligations and that are not. 
In particular, we analyse NGOs' counter-rhetoric and arguments on evasion of responsibility (including irresponsible disengagement) and lack of transparency in relation to workers' vulnerability.

\subsection{Evasion of responsibility}

Retailers that decide not to honour their contractual obligations or suddenly disengage from suppliers without concrete repercussions exhibit evasion of responsibility. For example, New Look, a British retailer, wrote to suppliers (as reported in the fashion newspaper Drapers, 3 April 2020):

In assessing what is in New Look's best interests ... New Look ... does not intend to pay you for any costs, including any costs for fabric and raw materials, in connection with any cancelled orders.

The note also clearly indicated the brand's intention to delay any payments indefinitely, suggesting that this is in 'New Look's best interests', and told suppliers '[t]his is a matter of survival'. This irresponsible disengagement did not pass unchallenged or unquestioned by NGOs and activists. In its \#PayUp petition (launched 30 March, statement 22 July 2020) an activist organisation, Remake, made the following statement on retailers' evasion of ethical responsibility:

COVID-19 has ravaged garment makers around the globe with a majority of fashion brands cancelling orders after a constriction in retail sales during the months of March and April. ... [T] his has caused millions of garment makers to be left unpaid for work they had already completed. With no access to savings, healthcare, or severance, these makers face critical food and housing insecurity.

This illustrates how evasion of responsibility by retailers through cancelling orders is putting workers on the edge of starvation and homelessness. Noticeably, activists are using strong rhetoric on the devastating impact of this ruthless decision, to stress the urgency of their claim, and employing vivid images and evocative ways of describing the situation to harness public support.

\subsection{Lack of transparency}

Up until July 2020, few retailers provided constructive responses to respecting workers' rights during the pandemic. A UK-based NGO, Traidcraft Exchange (2020), used a real-time tracker to monitor what the biggest UK fashion retailers disclosed up to 23 March 2020 to ascertain the level in the supply chain where they cancelled or changed order. It asked the biggest UK fashion retailers to answer six themed questions (about the crisis): public statement, paid suppliers for finished products, paid suppliers' costs, paid workers for past work, workers paid, workers paid during crisis and workers had protective equipment. Traidcraft Exchange disclosed the retailers' responses on their website, which we summarise in Table 2.

Table 2 shows that, until 23 March, 6 out of 14 major retailers stayed silent and disclosed no information, while 8 other companies mostly made general public statements rather than disclosing any specific or crucial items (e.g. workers paid for past work, workers paid during the crisis). In other words, eight companies publicly stated various (but in general significantly 
low) levels of engagement with their supply chains. Overall, Table 2 shows thin disclosures on workers' conditions during the pandemic, which indicates a lack of transparency and disengagement by UK retailers within global supply chains during the Covid-19 crisis. ${ }^{5}$

There are also obvious questions about whether the existing compliance mechanisms - the enforcement of ethical codes of conduct, factory audit or social audit-have really worked during the pandemic. Lockdowns and travel bans meant social audits of factories were discontinued at the peak of the pandemic (Just Style, 2020). Businesses were permitted not to disclose information about modern slavery within their supply chains. For example, the UK Home Office stated on its website on 20 April 2020 that ' $[\mathrm{b}]$ usinesses which need to delay the publication of their modern slavery statement by up to 6 months due to coronavirus- related pressures will not be penalised'. Furthermore, there have been reports that retailers - such as Arcadia, a British retailer - may have furloughed all or most of their CSR staff; on its website (last viewed 20 July 2020) LBL, a UK-based NGO, asked whether this decision should be seen as as 'a sign of lack of genuine commitment to ethical trading'.

Table 2. UK Major Fashion Retailers' Disclosures to Traidcraft Exchange (up until 23 March 2020)

\begin{tabular}{|l|l|l|l|l|l|l|}
\hline $\begin{array}{l}\text { Disclosure } \\
\text { Issue/ } \\
\text { fashion } \\
\text { retailers }\end{array}$ & $\begin{array}{l}\text { Public } \\
\text { Statement }\end{array}$ & $\begin{array}{l}\text { Paid } \\
\text { Suppliers } \\
\text { for Finish } \\
\text { Products }\end{array}$ & $\begin{array}{l}\text { Paid } \\
\text { Suppliers } \\
\text { Costs }\end{array}$ & $\begin{array}{l}\text { Workers } \\
\text { Paid for } \\
\text { Past Work }\end{array}$ & $\begin{array}{l}\text { Workers } \\
\text { Paid } \\
\text { during } \\
\text { Crisis }\end{array}$ & $\begin{array}{l}\text { Workers } \\
\text { have } \\
\text { protective } \\
\text { equipment }\end{array}$ \\
\hline Arcadia & No & No & No & No & No & No \\
\hline Asda & No & No & No & No & No & No \\
\hline Clarks & No & No & No & No & No & No \\
\hline $\begin{array}{l}\text { Edinburgh } \\
\text { woollen } \\
\text { Mill }\end{array}$ & No & No & No & No & No & No \\
\hline Matalan & No & No & No & No & No & No \\
\hline $\begin{array}{l}\text { Sports } \\
\text { Direct }\end{array}$ & No & No & No & No & No & No \\
\hline $\begin{array}{l}\text { John Lewis } \\
\text { Yes }\end{array}$ & $\begin{array}{l}\text { Some } \\
\text { progress }\end{array}$ & No & No & No & No \\
\hline Pentland & Yes & $\begin{array}{l}\text { Some } \\
\text { progress }\end{array}$ & NO & No & No & No \\
\hline Asos & Yes & $\begin{array}{l}\text { Some } \\
\text { progress }\end{array}$ & $\begin{array}{l}\text { Some } \\
\text { progress }\end{array}$ & No & No & No \\
\hline $\begin{array}{l}\text { Marks \& } \\
\text { Spencer }\end{array}$ & Yes & $\begin{array}{l}\text { Some } \\
\text { progress }\end{array}$ & No & No & No & $\begin{array}{l}\text { Some } \\
\text { progress }\end{array}$ \\
\hline Primark & Yes & $\begin{array}{l}\text { Some } \\
\text { progress }\end{array}$ & $\begin{array}{l}\text { Some } \\
\text { Progress }\end{array}$ & No & No & No \\
\hline Tesco & Yes & Yes & No & No & No & No \\
\hline Sainsbury & Yes & $\begin{array}{l}\text { Some } \\
\text { progress }\end{array}$ & Yes & No & No & No \\
\hline
\end{tabular}

\footnotetext{
${ }^{5}$ We communicated with Traidcraft Exchange, through email and telephone, about its ongoing tracking of fashion retailers' responses on the issues. In commenting on tracker (Table 2), a Traidcraft Exchange representative clarified the vulnerability of workers working for UK retailers as follows: 'What is particularly harsh is that there is no social safety net for garment workers. So, when there is no work, they [workers] have no access to food, and medical care, and might be evicted from their homes.'
} 


\begin{tabular}{|l|l|l|l|l|l|l|}
\hline Next & Yes & Yes & $\begin{array}{l}\text { Some } \\
\text { progress }\end{array}$ & Yes & No & $\begin{array}{l}\text { Some } \\
\text { progress }\end{array}$ \\
\hline
\end{tabular}

During the pandemic, failing to honour contractual obligations with suppliers not only exposes retailers' evasion of responsibility and lack of transparency but also perpetuates inequality, corporate hegemony and 'win-at-all-costs' neoliberalism, and the absence of any concrete repercussions for that failure reinforces NGOs' activism and counter-rhetoric. While the pandemic exposes retailers' lack of moral standing (Islam et al., 2020) (the micro-level), this also indicates a 'colossal failure' by neoliberalism (the macro level) (Magdaleno, 2020; Chomsky, 2020). On its website (last viewed 1 August 2020), the Clean Clothes Campaign (CCC), for example, put forward the following arguments against inequality and calls for action:

Apparel companies have profited for decades from low wage labour ... that lined the deep pockets of billionaire company owners and shareholders. By consciously taking the risk to build profits on the ultimate low-cost system ..., these companies now must face the consequences and pay workers what they are due.

This narrative suggests that 'pleasing profit over people' (Chomsky, 1999, p.26) or exploiting labour to maximise profit to shareholders and global brand owners in Northern countries is systemic in global supply chains, thereby depriving workers of social protection. Clearly, to strengthen the argument by increasing its emotional impact, rhetoric is employed such as 'build profits ... that lined the deep pockets of billionaire company owners'.

\section{Rhetorical strategies of retailers and counter-rhetoric by NGOs}

Table 3 illustrates some rhetorical strategies employed by global retailers, and counter-rhetoric and persuasive arguments deployed by NGOs and media apparently to challenge and delegitimise retailers' strategies.

\section{Table 3. Illustrations of rhetoric and counter-rhetoric strategies}

\begin{tabular}{|c|c|}
\hline $\begin{array}{l}\text { Rhetorical } \\
\text { strategies }\end{array}$ & Retailers' rhetoric versus NGOs' counter-rhetoric \\
\hline Justification & $\begin{array}{l}\text { Primark (British retailer) tried to justify cancelling orders, stressing the unprecedented } \\
\text { situation and 'no other option' ( Primark CEO's statement on its website, } 22 \text { March 2020) } \\
\text { while Remake (NGO) employed counter-retoric emphasising the devastating impact of } \\
\text { this decision: 'millions of mostly women garment makers will go hungry and be forced } \\
\text { onto the streets' (Remake website, } 22 \text { July 2020). }\end{array}$ \\
\hline $\begin{array}{l}\text { Misleading } \\
\text { commitment }\end{array}$ & $\begin{array}{l}\text { H\&M (Swedish retailer) suggested a commitment to corrective action by not renegotiating } \\
\text { prices (with suppliers) for already placed orders (H\&M Press Officer's comment to } \\
\text { media, reported in Forbes, } 30 \text { March 2020). Subsequently, Worker Rights Consortium } \\
\text { (WRC-NGO) asterisked H\&M on its Covid-19 tracker, which indicated suppliers' } \\
\text { concerns that H\&M had not honoured its commitment (BHRRC website, viewed } 2 \text { June, } \\
2020 \text { ). }\end{array}$ \\
\hline $\begin{array}{l}\text { Diversion of } \\
\text { attention }\end{array}$ & $\begin{array}{l}\text { Asda (British retailer) used a persuasive argument that, during Covid-19, it worked to 'do } \\
\text { the right thing', listing donations to the NHS and others (Asda website outlining Q1 } \\
\text { results, } 19 \text { May 2020). Countering this, WRC reported that Asda had abandoned suppliers }\end{array}$ \\
\hline
\end{tabular}


and left workers vulnerable. It made the opportunistic nature of Asda's ethical responsibility visible (WRC website, 1 May 2020).

Silence

$$
\begin{aligned}
& \text { Despite mounting public criticism, Kohl's (US retailer) did not disclose cancelled orders } \\
& \text { and the devastating consequence of this for workers. Amid the silence, Tell Kohl's } \\
& \text { (activist group) used counter-rhetoric, directly attacking Kohl's for paying millions of } \\
& \text { dollars to shareholders during a pandemic while workers were left with nothing (CCC } \\
& \text { website and Facebook, viewed } 28 \text { June 2020). }
\end{aligned}
$$

We found that a number of retailers used justification rhetoric. Primark, one of the first retailers to decide to cancel all orders, launched a misleading public relations campaign and published six related press releases. Its statement employed rhetorical techniques, e.g. parallelism and metaphor, to appeal to the emotions of the reader to reinforce the strength of its discourse, and to outline a convincing rationale. NGOs (for example, Remake) challenged Primark's justification by indicating that it had been employed to mask the reckless and greedy nature of an act that transferred the financial burden of the crisis to desperate workers struggling to put food on the table and to survive. Remake launched its \#PayUp campaign using counterrhetoric to stress the urgency of the situation for workers who are mostly women (see summary in Table 3). At the micro-level, Remake's rhetoric appears as an emancipatory counter-account (Gallhofer et al., 2006) and, without this, Primark's behaviour during the pandemic would be less visible.

We also found three press releases by C\&A, a European retailer, that has shifted its position considerably under public pressure but stayed on the blacklist side of the WRC tracker. The brand justified its action in a press release published on 24 April:

The lack of certainty ... left us with no other option at that time than to take drastic and immediate action ... and to carefully look at what business options may possibly be available ...

WRC (27 May 2020) mobilised emotive counter-rhetoric, stating:

$C \& A$, via COFRA Holding, is under the exclusive ownership and control of the Brenninkmeijer family ... the richest family in the Netherlands. Recently available reports put the family's wealth at $\$ 22$ billion ... [B]illionaires should not be seeking to offload the economic burden of the pandemic onto workers in Bangladesh and Cambodia who subsist on a few dollars a day.

Another rhetorical strategy, misleading commitment, conveys an overall message that implies a commitment where no (or little) action is actually taken in the future. Unsurprisingly, C\&A was one of the first few retailers to use the rhetoric of (misleading) commitment to corrective action (H\&M was another), vowing to honour its payments; nonetheless, C\&A stayed on the negative side of the WRC tracker. It stated in a press release published on 24 April:

In discussions with our suppliers, we have reassured them that we will reinstate and pay for the majority of orders - to date $93 \%$ of all orders. In the coming weeks, we will work on solutions regarding the remaining $7 \%$.

This narrative was partially contradicted by reports from suppliers indicating that reinstated orders, while sizable, represent a smaller percentage of the total (WRC website, 27 May 2020). WRC also claimed that C\&A's approach has been manipulative, considering that it has delayed both taking delivery and payment, for as long as a year, which is no better than outright cancellation for some suppliers. 
Consistent with the strategy Diversion of attention, Asda published a press release on 19 May stating 'through_Covid-19 we have worked to invest in doing the right thing listing a number of donations to NHS [National Health Service] and so on' (Table 3). Asda's narrative was clearly contradicted when NGOs (such as WRC on its website, 1 May 2020) documented that, while supporting the UK NHS, Asda had abandoned its suppliers, refusing to accept up to $20 \%$ of orders shipped to Asda before the crisis began and demanding price reductions on orders completed but not yet shipped ranging from $40 \%$ to $70 \%$; unlike other brands, it stayed open during the lockdown, attaining record food sales. WRC counter-rhetoric against ASDA's action defined it as 'opportunistic' in a way that ignores moral commitments, putting its private interests ahead of workers' rights (Table 3). This is a classic example of how, during the pandemic, a big retailer like Asda gains at the expense of poor workers in the developing world - in other other words, firm-level 'opportunistic' behaviour into which macro-level 'colossal failure' (Chomsky, 2020; Magdaleno, 2020) and the global hegemony of neoliberalism are implicated.

The rhetoric of silence is also a powerful strategy that corporations might use to advance their hegemonic interest (Chwastiak \& Young, 2003; Semeen \& Islam, 2020). Significantly, some retailers have preferred to stay silent in the face of mounting criticism and, by remaining silent, ignoring accusations of wrongdoing. For example, Kohl's opted for silence. It informed suppliers in mid-March, via conference call, that it will not pay for its orders, even those that have already been produced (WRC website, 17 June 2020). It seems the company has a clause in its contracts permitting it to cancel contracts any time without giving any reason. In response to this, on 17 June 2020 the WRC stated:

It is notable that the actions of Kohl's-which a reasonable observer might consider to be little more than outright robbery - are probably legal.

Using metaphoric wording that conceptualises Kohl's behaviour as 'outright robbery' represents strong rhetoric that indicates enormous, unbalanced power relations between the brand and its suppliers that lead to extreme forms of exploitation.

Furthermore, The Guardian newspaper reported on 10 June, about Kohl's social behaviour, that:

Kohl's ... cancelled millions of dollars' worth of existing orders from Bangladeshi and Korean garment factories just weeks before paying out $\$ 109 \mathrm{~m}$ ( $\$ 85 \mathrm{~m}$ ) in dividends to shareholders.

Obviously, this indicates outrage at this move from a brand that has rewarded its shareholders at the expense of struggling suppliers and desperate workers. A similar narrative was also produced by CCC (2020, viewed on 28 June 2020) posted on its Facebook page (see Table 3). Manifestly, CCC used outrage at Kohl's announcement of shareholder payment to name and shame the brand using emotive rhetoric; however, Kohl's stayed silent in the face of this mounting criticism.

In summary, during the Covid-19 pandemic, global retailers adopted the rhetorical strategy of justifying their actions, provided misleading commitments to workers, used enhancement strategy to divert attention, and kept silent about negative information to downplay it. As evidenced, the counter-rhetorics mobilised by NGOs challenge corporate accounts, making visible the role of neoliberal doctrine (Chomsky, 1999) in abusing workers rights. NGO counter-rhetoric highlights the disengaged, irresponsible action/inactions of MNCs 
contributing to the plight and vulnerability of workers during 2020. Arguably, while neoliberal mechanisms operate as 'hegemonic projects' (Ala and Lapsley, 2019), at the macro level, such counter-rhetoric has an emancipatory role in challenging the hegemony.

\section{Conclusion and future research directions}

This research investigates rhetoric used by global clothing retailers and counter-rhetoric deployed by NGOs in relation to workers' rights during the Covid-19 pandemic. While retailers have used rhetorical strategies to conceal or silence injustices to workers in the supply chain, NGOs have used counter-rhetoric to reveal structural injustice and systemic inequalities that have left workers without social protection. In other words, while corporate rhetoric has been used more to mislead than to convince a readership, counter-rhetoric has exposed misleading organisational behaviour in an attempt to delegitimise ways in which they operate (including transparency and disclosure practices).

Our analysis provides evidence of how a lack of transparency by retailers and irresponsible disengagement from global supply chains were prevalent during the early months of the pandemic. It also makes a case that neoliberal corporate transparency policies - such as social disclosure and social audits - have been ineffective or even inactive at a time when workers in global trade have suffered. Our research provides new insights into NGOs' counter-accounts and adds to existing accounting literature (Semeen \& Islam, 2020; Chwastiak \& Young, 2003; Lehman et al., 2016) that addresses corporate social disclosures/transparency and social inequality. Our findings suggest that NGOs' narratives have an emancipatory power to challenge micro-level neoliberalism, which is implicated in macro changes often linked to politics and policymaking. We encourage further research to investigate how neoliberal transparency and accountability regulations (at the macro level) impact workers' livelihoods in global supply chains in the post-Covid-19 world. In addition to this, there are ample opportunities for future critical and interdisciplinary accounting research in relation to different accountability and transparency topics evolving out of Covid-19. The following are a few examples of topics that are worthy of future research in the related area:

- While Covid-19 is significantly impacting the human rights and vulnerability of factory workers within the global supply chains, the new and evolving tensions around (lack of) accountability of retailers and their (direct) regulators based on core nations (developed nations) deserves further research attention. The future research needs a macro-level framework such as the World System Theory (Wallerstein, 1987, 2016), a post-colonial theory (Said, 1978) to problematise how core nations and their corporations, through the evolving human rights disclosure regulations (such as UK Modern Slavery Act 2015; Australian Modern Slavery Act 2018; EU due diligence rules 2021) are maintaining the post-pandemic 'global order' in the supply chains operating in the periphery (developing) countries.

- Related to our research, we observe that social audit practices within the global supply chains are impacted by the Covid-19 pandemic. NGOs and labour rights bodies are concerned that some retailers have stopped carrying out social audits (The Gurdian, 2020). Many may have found the pandemic a handy excuse to avoid using social audits. Prior research (Islam et al., 2018; 2021) revealed that the way social audits are used often does not protect workers' rights at garment factories. A few studies (see, for example, Islam et al., 2021) also acknowledge that the audit itself cannot change a 
situation; instead, it is what is to be done with the audit result. We urge further research to understand whether and how the absence (or limited use) of social audits during the pandemic appears to have made forced labour conditions and women's vulnerability worse.

- With covid-19 continuing to impact people and their vulnerability, businesses, in particular, are struggling to find the (new) ways to legitimise their operations and survive in the community in which they operate. We encourage research to look at how the struggles of businesses during the pandemic cause their performance measurements, accountability and transparency to shift and to what extent this allows accountants and auditors to play their roles, if any.

- Undoubtedly, like any other profession, the accounting profession is impacted by the Covid-19 pandemic. Accountants and accounting firms, along with some traditional ethical challenges such as manipulations of financial statements, tax avoidance, conflict of interests and socially irresponsible actions, are now experiencing new challenges such as working from home, audits at a distance or audit without any physical verifications and risk of unique nature of frauds during the pandemic time. Covid-19 related panic and fear appear to have led more individuals and businesses to act unethically, leaving accountants in the middle of a new crisis. The panic and uncertainty during pandemic seem to have increased call for more transparency and accountability in accounting bodies' operating practices, deserves future research attention. 


\section{References}

Ala, A.S. and Lapsley, I., (2019). "Accounting for crime in the neoliberal world". The British Accounting Review, Vol. 51, No. 5, p.100839.

Arnold, P.J. (2009), "Global financial crisis: the challenge to accounting research", Accounting, Organizations and Society, Vol. 34 Nos 6/7, pp. 803-9.

Benoit, W. L. (1995). Accounts, excuses, and apologies: A theory of image restoration strategies, State University of New York Press, NY.

Brennan, N. M. \& Merkl-Davies, D. M. (2014). "Rhetoric and argument in social and environmental reporting: the Dirty Laundry case". Accounting, Auditing \& Accountability Journal, Vol. 27 No. 4, pp. 602-633.

Bryant, T., Aquanno, S. \& Raphael, D., (2020). "Unequal Impact of COVID-19: Emergency Neoliberalism and Welfare Policy in Canada". Critical Studies: An International and Interdisciplinary Journal, Vol.15 No. 1, pp.22-39.

Chomsky, N. (1999). Profit over people: Neoliberalism and global order: Seven Stories Press.

Chomsky, N. (2016) Chomsky On Neoliberalism: 'It's Not New And It's Not Liberal' viewed on 14/01/2021 at: https://kitoconnell.com/2016/09/15/chomsky-neoliberalism-profitgoes-apple-microsoft-not-taxpayer/

Chomsky, N. (2020) Author Noam Chomsky explains why the 'neoliberal doctrine' has intensified the deadly effects of COVID-19, July 07, 2020. https://www.alternet.org/2020/07/author-noam-chomsky-explains-why-neoliberaldoctrine-has-intensified-the-deadly-effects-of-covid-19/

Chiapello, E. (2017). "Critical accounting research and neoliberalism". Critical Perspectives on Accounting, Vol. 43, pp. 47-64.

Chwastiak, M. \& Young, J. J. (2003). "Silences in annual reports". Critical Perspectives on Accounting, Vol.14 No. 5, pp. 533-552.

Connolly, N. \& Kaisershot, M. (2015). “Corporate power and human rights”. The International Journal of Human Rights, Vol. 19 No. 6, pp. 663-672.

Cooper, C., Danson, M., Whittam, G. \& Sheridan, T. (2010). "The neoliberal project-Local taxation intervention in Scotland". Critical Perspectives on Accounting, Vol. 21 No. 3, pp.195-210.

Deegan, C. \& Islam, M.A., (2014). "An exploration of NGO and media efforts to influence workplace practices and associated accountability within global supply chains". The British Accounting Review, Vol. 46, No. 4, pp.397-415.

Denedo, M., Thomson, I. \& Yonekura, A. (2017). "International advocacy NGOs, counter accounting, accountability and engagement". Accounting, Auditing \& Accountability Journal, Vol. 30 No. 6, pp. 1309-1343.

Ellwood, S. \& Newberry, S. (2007), "Public sector accrual accounting: institutionalising neoliberal principles?", Accounting, Auditing \& Accountability Journal, Vol. 20 No. 4, pp. 549-73.

Erkama, N. \& Vaara, E. (2010). "Struggles over legitimacy in global organizational restructuring: A rhetorical perspective on legitimation strategies and dynamics in a shutdown case". Organization Studies, Vol. 31 No. 7, pp. 813-839.

Fincham, R. \&Forbes, T. (2019). "Counter-rhetoric and sources of enduring conflict in contested organizational fields: A case study of mental health professionals". Journal of Professions and Organization, Vol. 6 No. 3, pp. 342-356.

Gallhofer, S., Haslam, J., Monk, E. \& Roberts, C. (2006). "The emancipatory potential of online reporting”. Accounting, Auditing \& Accountability Journal, Vol. 19 No. 5, pp. 681-718. 
International Labour Organization (ILO) (2020). "Recommendations for garment manufacturers on how to address the COVID-19 pandemic", Available at: https://www.ilo.org/wcmsp5/groups/public/---asia/---robangkok/documents/briefingnote/wcms_741642.pdf.

Islam, M.A. (2020), "Coronavirus measures give Bangladeshi workers for global clothing chains a stark choice: disease or starvation", Available at: http://www.asiascot.com/news/2020/07/02/coronavirus-measures-give-bangladeshiworkers-for-global-clothing-chains-a-stark-choice-disease-or-starvation/.

Islam, M. A., Deegan, C. \& Gray, R. (2018). "Social compliance audits and multinational corporation supply chain: evidence from a study of the rituals of social audits". Accounting and Business Research, Vol. 48 No. 2, pp.190-224.

Islam, M. A., Deegan, C. \& Haque, S. (2020). "Corporate human rights performance and moral power: A study of retail MNCs' supply chains in Bangladesh”. Critical Perspectives on Accounting, 102163.

Just Style (2020). "Social compliance auditing during and after Covid-19”, May 7, Available at: https://www.just-style.com/comment/social-compliance-auditing-during-and-aftercovid-19_id138647.aspx.

Kılıç, S. (2020). "Does COVID-19 as a Long Wave Turning Point Mean the End of Neoliberalism?", Critical Sociology, p.0896920520980083.

Lehman, C., Annisette, M. \& Agyemang, G. (2016). "Immigration and neoliberalism: three cases and counter accounts". Accounting, Auditing \& Accountability Journal, Vol. 29 No. 1, pp. 43-79.

Magdaleno, C. (2020), "Chomsky on COVID-19: The latest massive failure of neoliberalism, Euractiv", May, 6 viewed at https://www.euractiv.com/section/economyjobs/interview/chomsky-on-covid-19-the-latest-massive-failure-of-neoliberalism/

Morales, J., Gendron, Y. \& Guénin-Paracini, H. (2014). "State privatization and the unrelenting expansion of neoliberalism: The case of the Greek financial crisis". Critical Perspectives on Accounting, Vol. 25 No. 6, pp.423-445.

Navarro, V. (2020). "The Consequences of Neoliberalism in the Current Pandemic". International Journal of Health Services, 0020731420925449.

Neilson, D. (2020). "Epistemic violence in the time of coronavirus: From the legacy of the western limits of Spivak's 'can the subaltern speak' to an alternative to the 'neoliberal model of development", Educational Philosophy and Theory, 00131857.2020.1750092.

Said, E. (1978). Orientalism: London: Penguin Books.

Semeen, H. \& Islam, M. A. (2020). "Social impact disclosure and symbolic power: Evidence from UK fair trade organizations". Critical Perspectives on Accounting, 102182.

Shamir, R. (2008). "The age of responsibilization: On market-embedded morality". Economy and Society, Vol. 37 No. 1, pp.1-19.

Shrives, P. J. \& Brennan, N. M. (2017). "Explanations for corporate governance noncompliance: A rhetorical analysis". Critical Perspectives on Accounting, Vol. 49, pp.31-56.

Sikka, P. (2011). Accounting for human rights: "The challenge of globalization and foreign investment agreements". Critical Perspectives on Accounting, Vol. 22 No. 8, pp.811827.

Suddaby, R. \& Greenwood, R. (2005). "Rhetorical strategies of legitimacy". Administrative Science Quarterly, Vol. 50 No. 1, pp. 35-67.

The Guardian (2020),"We are on our own': Bangladesh's pregnant garment workers face the sack", July, 9 last viewed on May, 15, 2021 at https://www.theguardian.com/global- 
development/2020/jul/09/we-are-on-our-own-bangladeshs-pregnant-garmentworkers-face-the-sack.

Traidcraft Exchange (2020). "Fast Fashion Crisis: How are the brands responding", last viewed on July 15 at https://traidcraftexchange.org/fast-fashion-how-are-brands-responding.

Tregidga, H. (2017). "Speaking truth to power": Analysing shadow reporting as a form of shadow accounting. Accounting, Auditing \& Accountability Journal, Vol. 30 No. 3, pp. $510-533$.

UNCTAD, (2020). Impact of the COVID-19 Pandemic on Trade and Development: Transitioning to a New Normal. https:/unctad.org/system/files/officialdocument/osg2020d1_en.pdf

Vinnari, E. \& Laine, M. (2017). "The moral mechanism of counter accounts: The case of industrial animal production”. Accounting, Organizations and Society, Vol. 57, pp. 117.

Wallerstein, I. (1987). World-systems analysis. Stanford: Stanford University Press.

Wallerstein, I. (2016). Antisystemic movements, yesterday and today Social Movements and World-System Transformation, in J. Smith, M. Goodhart, P. Manning, J. Markoff, (Eds.), Social Movements and World-System (5-14). New York: Routledge 